\title{
Blocking Effect of Tripelennamine on Histamine- Induced Positive Ghronotropic and Inotropic Responses of the Dog Atrium
}

\author{
Shigetoshi Chiba \\ Department of Pharmacology, Faculiy of Medicine, Shinshu \\ University, Matsumoto 390
}

\begin{abstract}
Chuвa, S. Blocking Effect of Tripelennamine on Histamine-Induced Positive Chronotropic and Inotropic Responses of the Dog Atrium. Tohoku J. exp. Med., $1976,120(3), 299-300$ - The effects of histamine on inotropic and chronotropic activity were investigated in isolated canine atrium preparations which were suspended in a bath and perfused with arterial blood from a carotid artery of heparinized support dog. Histamine administered into the cannulated sinus node artery in a dose range of $0.3-100 \mu \mathrm{g}$ produced dose-related positive chronotropic and inotropic effects. The positive responses to histamine were not suppressed by treatment with propranolol in doses which blocked responses to norepinephrine, but these were significantly suppressed by a histamine $\mathrm{H}_{1}$ receptor blocking agent, tripelennamine. On the other hand, these histamine-induced effects were not modified by a histamine $\mathrm{H}_{2}$ receptor blocking agent, burimamide. From these results, it is assumed that positive chronotropic and inotropic effect of histamine may be mediated by histamine $\mathrm{H}_{1}$ receptors in the dog heart. - - histamine $\mathrm{H}_{1}$ and $\mathrm{H}_{2}$ receptors; $\mathrm{SA}$ node; atrial contractility; burimamide
\end{abstract}

In 1960, Trendelenburg reported that histamine exerted a positive chronotropic effect on isolated guinea-pig, rabbit and cat atria which was not specifically antagonized by mepyramine or tripelennamine, one of histamine $H_{1}$ receptor blocking agents. Recently Black et al. (1972) showed that burimamide, a histamine $\mathrm{H}_{2}$ receptor blocking agent, could antagonize the increases in rate of the isolated guinea-pig atria in response to histamine. They have classified histamine receptors into $\mathrm{H}_{1}$ and $\mathrm{H}_{2}$ receptors. $\mathrm{H}_{1}$ receptors mediate most effects of histamine and are blocked by classical antihistaminic compounds (histamine $\mathrm{H}_{1}$ receptor blocking agents). $\mathrm{H}_{2}$ receptors, on the other hand, appear to mediate the gastric secretory and cardiac stimulatory effects of histamine and are not blocked by $\mathrm{H}_{1}$ receptor antagonists. However, there is no available report of action of histamine on isolated dog hearts. Thus, in this study, it was investigated whether cardiac stimulating effect of histamine is mediated by $\mathrm{H}_{1}$ receptors or $\mathrm{H}_{2}$ receptors in the isolated dog atrium.

Six isolated atria were used for observations of effect of tripelennamine, $H_{1}$ receptor blocking agent, on positive chronotropic and inotropic actions of histamine. These preparations were perfused with heparinized arterial blood led from a support dog anesthetized with $30 \mathrm{mg} / \mathrm{kg}$ of sodium pentobarbital. The details of the preparations were described in a previous paper (Chiba et al. 1975).

When histamine, $0.3-100 \mu \mathrm{g}$, was injected into the cannulated sinus node artery of the isolated right atrium, positive chronotropic and inotropic responses were dose-relatedly increased. When tripelennamine, $30-300 \mu \mathrm{g}$, was injected into the sinus node artery, negative chronotropic and inotropic effects were dose-relatedly induced. Occasionally,

Received for publication, July $26,1.976$. 


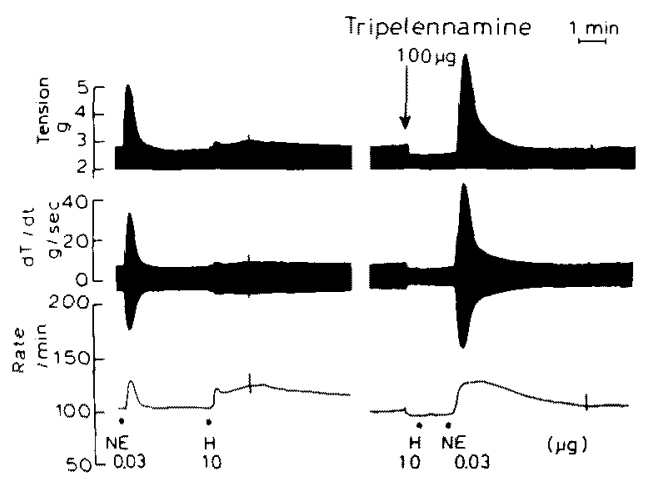

Fig. 1. Effect of $100 \mu \mathrm{g}$ of tripelennamine on positive chronotropic and inotropic responses to $0.03 \mu \mathrm{g}$ of norepinephrine $(\mathrm{NE})$ and to $10 \mu \mathrm{g}$ of histamine $(\mathrm{H})$ in an isolated canine atrium.

positive chronotropic and inotropic effects of tripelennamine followed just after negative effects. At a large dose of $1 \mathrm{mg}$ of triplennamine, sinus arrest was frequently observed. The positive responses to $1-30 \mu \mathrm{g}$ of histamine were significantly suppressed by pretreatment of the tissue with doses of tripelennamine $(30-300 \mu \mathrm{g})$ which rather enhanced the actions of norepinephrine. Fig. 1 shows traces from such an experiment. On the other hand, a histamine $H_{2}$ receptor blocking agent, burimamide $(1 \mathrm{mg})$, did not significantly suppress effects of histamine $(3-10 \mu \mathrm{g})$ in 5 experiments.

From these results, it is assumed that positive chronotropic and inotropic effect of histamine may be mediated by histamine $\mathrm{H}_{1}$ receptors in the dog heart, indicating species differences with respect to histamine receptors on the heart.

\section{References}

1) Black, J.W., Duncan, W.A.M., Durant, C.J., Ganellin, C.R. \& Parsons, E.M. (1972) Definition and antagonism of histamine $\mathrm{H}_{1}$-receptors. Nature (Lond.), 236, 385-390.

2) Chiba, S., Kimura, T. \& Hashimoto, K. (1975) Muscarimic suppression of the nicotinic action of acetylcholine on the isolated, blood-perfused atrium of the dog. NaunynSchmiedeberg's Arch. exp. Path. Pharmak., 289, 315-325.

3) Trendelenburg, U. (1960) The action of histamine and 5-hydroxytryptamine on isolated mammalian atria. J. Pharmacol. exp. Ther., 130, 450-460. 